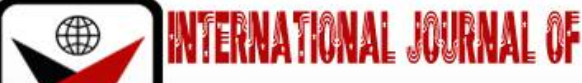

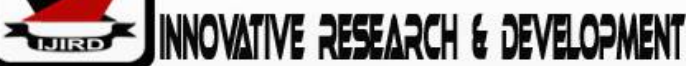

\section{Shifting the Paradigm of Ududu-Eze: The Mystical Pot of Clay from Aguleri which Severs as the Symbol of Power That Creates the Eze Nri in Igbo Traditional Religion}

\author{
Dr. Madukasi, Francis Chuks
Lecturer, Department of Religion \& Society,
Chukwuemeka Odumegwu Ojukwu University, Nigeria
}

\begin{abstract}
:
Like almost all tradition, kingdom has been able to show spiritual force which affects royal families. This tradition has been seen everywhere like Europe, America, Asia and Africa etc. Especially for Eri kingdom it is a kingly festival especially Nri without 'Ududu-Eze' the covenant pot of clay, the coronation will not take place. In Igbo tradition, this symbol of kingship is symbol of authority, Kingship and leadership and it act as a spiritual conduit that binds or compensates the communities that make up the Eri kingdom through the mediation for the loss of their contact with their ancestral home and with the built/support in religious rituals and cultural security of their extended brotherhood. This festival is usually an occasion for jocundity and thanksgiving; people appear in their best and give of their best. The offerings are mostly thank-offerings, and the meals constitute an opportunity of communion between the divinity and his 'children'. This paper focuses on how this renewal of covenant relationships between communities is done to reunite their intimate brotherhood and to show how the Aguleri community uses this ritual pot of clay to reassert her position as the true head of the Igbo through the mediation ofstages of ritual journey coronation festival to show their gratitude to their gods and ancestors for various reasons known to them and consequently commemorates Eri as their great ancestor for instituting the Ududu-Eze as a symbol of the power that creates Eze Nri.
\end{abstract}

Keywords: Brotherhood, Communion, Deities, Eri,Ritual, Symbolism, Ududu-Eze

\section{Origin and Migration}

Etymologically, the wordUdudu-Eze is an Igbo coinage that means the King's royal pot of clay and according to Nzewi (2000:25) theUdudu-Eze. Isichei (1980:2) argues that Aguleri hardly has anything to visit. Houses are following the classic Igbo pattern and far away from the road. A long history, along with mythology, recalls a man called Eri, sent from God, who lived there". The words Igbo, Ibo, Ebo, HEEBO are said to be a corruption of the name, Hebrew. As D. J Wiseman pointed out through the mouth of (Ikeanyibe, 1999:10) "the word Hebrew in Jewish language meant wanderer or a people with no secure place in society".

\section{Settlement}

Eri, the founder of Igbo race was among the migrants and he was believed to have moved and settled temporarily with his followers, in an area near the confluence of the Niger and Benue Rivers (Ikeanyibe, 1999:11 \& Idigo, 2001:72). From there Eri moved to the Anambra valley and quickly settled near the bank of the River Omanbala [corruptly called Anambra by the Europeans] at a place known as Eri-Aka near Odanduli stream, which is presently today located between Ivite and Igboezunu Aguleri respectively. It is pertinent to mention here that some scholars like Afigbo (1983:8) in his article claims that "this special creation of Eri was said to have taken place in the area where Aguleri is now situated. Reviewing this assertion made by Afigbo, I must say that this paragraph is highly mitigated; filled with fabricated liars, misinterpretations; misrepresentations and distortion of time honoured historical facts because in Igbo culture and tradition it is a known fact the Aguleri is the first son of Ancestor Eri. It is also a known fact that under inheritance traditional laws and customs of the Igbo that the first son must take over his father's house - Obu /Obiafter the death of his father. Nonetheless, for Afigbo to claim that Nri is the first born of Eri is fallacious, which constituted an academic fraud and it is totally unacceptable and I advise that he should carry out his research properly. No wonder Williams (1988:79) warns that this kind of formulation about inheritance is "misguided and wrong, but that such crookedness must finally be rejected out of hand". However, through the institutions and mediation of royal ordination and ceremonial rituals and spirit manifestation, Aguleri reasserted and repositioned in this way to her authority over other Igbo's in diaspora to "represent the headship of Igbo race" (Nnamah, 2002:9). Nnamah (2002:9) again asserts that "it is also very vital to mention here that Aguleri is strategically located at the point of origin of Igbo land from where Igbo land spread further into the hinterland".To digress a bit and to put the record straight, the position of Nri as a priest and ritual specialist is never contested in Igbo cosmology. Reasserting this, Idigo comments that "Menri, the founder of Nri was recognized as the 
priest and spiritual specialist who travelled throughout Igbo land and had the authority to offer sacrifices and absolve criminals from the wrath of the gods that is 'Ikpu Alu'. In a mixed gathering of Igbos, no Nri man breaks kolanut in the presence of Aguleri man. The Nri man respects the seniority of Aguleri and gives him the honour to break kolanut as the head of Eri family" (2001:50).

As a point of emphasis, Aguleri has as an ancient cultural community has been commemorating this festival in honour of Eri but only recently that the Ohanaeze Ndi Igbo, a pan Igbo group has officially instituted this ritual festival in the Igbo lunar and ritual calendar of the Igbo custom and tradition in order to honour Eri as the progenitor of the Igbo race. In reaffirming this position, Paul Nnamah, (2002:9) argues that significance attraction is present in Aguleri which makes it a stronger claim to originality (Nnamah, 2002:9). It has been called "structured self-image" by McAdams (1988:18). Capwell (1993:96), called it a centre of great tradition.

\section{Ancestral Worship}

According to Idigo (1990:60), Chi-Ukwu is the one God believed by all Aguleri people. They had a belief that the gods is not of fear but of friendship (Uchendu, 1965:101).

\subsection{Significance of the Festival}

It is on this note that De Heusch (1994:233) states that the river marks the border between two cosmic realms, where the "spiritual power or powers" lay (Nabofa, 1994:15). Parrinder (1969:58) describes "such sacred place as the home of powerful spirits, whom their leader often represented as a great king who lives in an underwater palace with mermaids and mermen as his attendants. From time to time he tries to flood the earth, and in some stories there may be links with Asian tales of a primitive deluge". (Eyisi, 2010:10). Isichei (1976:4); Onwuejeogwu (1981:22) \& Xrydz-Eyutchae (1986:11) affirm that it is "from this point each settlement pursued its own separate existence and development, owing allegiance to Aguleri, where the collective ancestral temple of Eri still stands to this day". It is on this position that Onwuejeogwu (1981:168) further explains that "the Nri Kingship has a deep and long connection with Aguleri". As a point of emphasis, "Aguleri people speak an Igbo dialect with a kind of elision that is not easy to follow or understand, and for this theory to be disclosed one has to try to play on the tonal sound of their names and even their local dialect when actually pronounced with original and unrefined Igbo cadence" (Madukasi, 1999: 69). There has been always the problem on the correct spellings of certain words like Obu /Obi, Obuga / Obugad, Uga, Ovo, Ofo by some scholars. To reduce the confusion of this phonetic, tonal and dialectic issue considerably, it would be advised that the generic term referring to house / sanctorumof Gador the scepter of Authorityfrom the vernacular term peculiar to Aguleri as an ethnic group should be applied.

However, according to Onwuejeogwu (1981:114) again "in the first level only the temple of Uga was formed. It was the temple of Eri, in Aguleri. All successors to the throne of Eze Nri must visit the temple of Uga during the coronation to perform the rituals of presentation, re-enactment and integration". He argues that "the political significance of the temple s generally uppermost in the minds of the Nri traditional elite, the ozo titled men" (Onwuejeogwu, 1981:114).To ascertain the authenticity and significance of this site to the tradition, culture and hegemony of the Igbo people, Jeffreys, (1935:347); Idigo, (2001:42) \& Onwuejeogwu, (1981:87) echoes that "this is why before any Nri traditional ruler is installed, the king is led to Aguleri where he performs sacrifices to the sacred temple of Obuga before being given the scepter of authority or Ududu Eze by the Igwe of Aguleri". It is during this kind of ritual coronation ceremony that the new Igwe elect of the Nri people would pay homage to some deities/shrines like Okpanime, Oye, Otutunzu where two rivers meet (Agbanabo) all in Agulei. Nabofa (1994:37) affirms that through the mediation and assistance of the traditional prime minister of the Aguleri, "these kinds of rituals are rigidly and meticulously followed so that they can retain their ancient, ritualistic and spiritual values as revealed and decreed by the divine in order to avoid sacrilege". No wonder Igwah et al (2014) echoes that "Obu-gad is a place for spiritual re-dedication and the evocation of the proud ancestry of Eri descendants and Ndi-Igbo in general. It is a sacred place for royal empowerment and self-purification".

In Traditional Igbo belief system, it is believed that rituals are performed by traditional elders in such ancient community like the Aguleri because they are regarded as the custodians of tradition, custom and hegemony and according to Waterman (1955:49) such "only old men in the community knew the entire ceremonial...repertory".For this reason, some Igbo ethnographers of the South-Eastern region of Nigeria concludes that Aguleri as an ancient kingdom for "so long is respected for clinging to the ways of their ancestors" irrespective of the fact that they embraced Christianity which encompasses civilization and modernization (Paredes, 1995:355).

\section{Coronation of Eze Nriand the Spiritual Nexuswith the Ududu-Ezein Igbo Cosmology}

In fact, in Igbo cosmology the coronation ritual ceremony of an Nri king would not be complete if 'Ududu-Eze' is not handed over to the acclaimed king to be by the traditional ruler of Aguleri (Idigo, 2001:42). Nabofa (1994:55) describes such sacred pot as "the power house of power in the home or community". This sacred or mythical pot called Ududu-Eze without which, no celebration or ritual would be complete (Babey, 1976:24). Isichei (1980:2), claimsthe Aguleri as the cradle of Igbo civilization. Mbiti (1975:144) argues that such places as sacred or holy. Chidester (1992:10) explains that such sacred place is inhabited by the dead, a domestic space in which the ancestors resides or visits (Chidester, 1992:11). Olsen (2004:13) observes that some supernatural occurs. As Lovell (2002:23) has pointed out, "such territory or space is characterized both as a metaphysical domain. Weightman (1996:59) argues it by calling it "as sacred places are created, an inner light outweighs outer darkness and a spiritual journey commences". Other forms of spiritual protections have been highlighted by Falola \& Essien (2007: xiii).Peters (2002:23) asserts it as a place where deities helps human by 
fulfillment of wishes, maintaining the status quo. Brown (2004:164) posits that such places are where traditional religious ties tend to compensate the communities like those ones that make up the Eri kingdom.

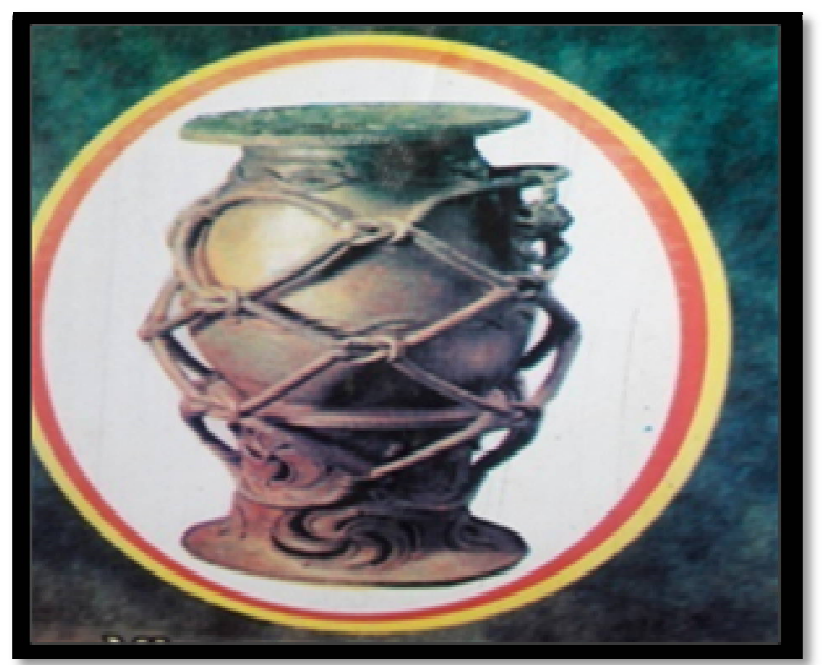

Figure 1: The Picture of Udu-Eze the covenant Pot of Clay That Severs as a Binding Force and Cements the Ritual Symbolism of Brotherhood in the Coronation of Kings in Eri Kingdom in Igbo Tradition (Courtesy of Madukasi Francis Chuks)

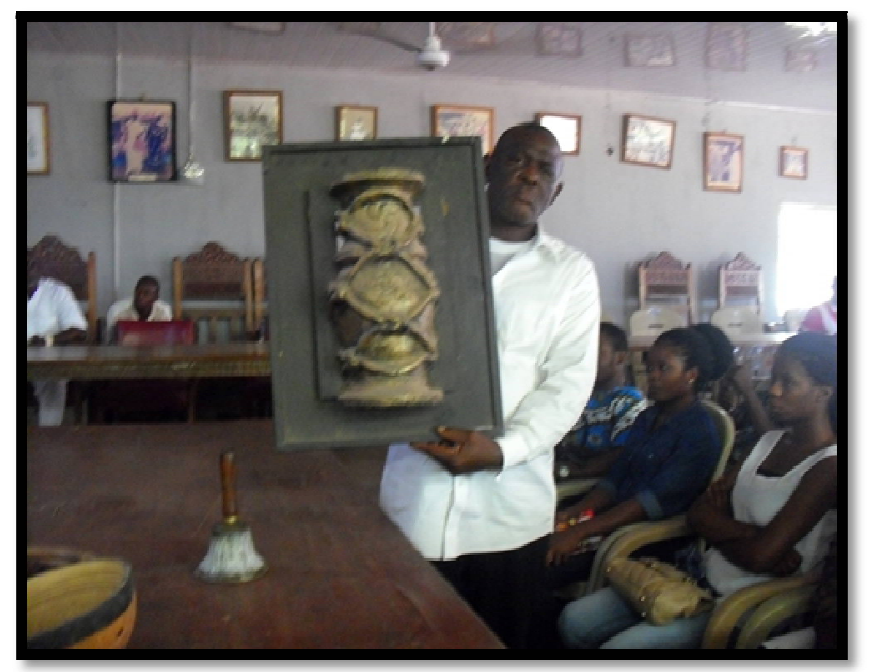

Figure 2: A Sculpture art work of Ududu-Eze at the palace of His Royal Majesty Igwe ObidiegwuOnyesoof Nri being displayed to students of Chukwuemeka Odumegwu Ojukwu University on cultural visitin 2017 (Courtesy of Madukasi Francis Chuks)

This means that there is synergy between the seen and unseen worlds making Aguleri to be the epicenter of spiritual and cultural home of the Igbo people. It is on this position that Macdonald (2004:317) argues that 90 per cent of the indigenes like that of Aguleri "identify themselves as Christians, but at the same time they continue to assert the tradition and hegemony of their ancestors". In this position, Kaplan (2000:122) observes that such rituals are still observed and maintained today by the traditionalists in the community and "even among most members who have converted to dominations of Christianity".Such occasion "serve as a catalyst in cementing people's solidarity" (Dube, 1996:110), and in order wards the community "are dancing on the shoulders of their ancestors" (Glocke \& Jackson, 2011:6), through the mediation of "ordered hierarchy from deity to man" (Rowe, 2008:32).

llesanmi (1996:2) argues that it cannot be denied that the entire community, including the $82 \%$ who are said to be Catholics, under the symbolic shadow of ancestorship hold great ancestor like Eri in high esteem probably not as a deity, but purely as an ancestor of the community, a great grandfather of high dignity whose influence is still currently felt in the town politically, socially and religiously. Most importantly is the fact that the cosmogonic myth about Eri and the commemoration of his coming "provided an ideological inclusive arena for communal ritual, blending and uniting the various communities at a crucial juncture" (Levine, 1997:196).

\section{Olili Obibia Eriand the Concept of Brotherhood}

The ritual festival called olili obibia Eri was designed as a unifying force for the Igbo's both at home and elsewhere. It features religious ceremonies, agricultural trade fairs, dancing and musical entertainments. All these served to strengthen and demonstrate the bond of union that kept both Aguleri and his dispersed brothers together. Thus Eri festival was initiated by Eri himself in a form of a miniature, yearly ritual celebration to remember his arrival at Agbanabo 
Ezu-na-Omambalarivers) and to thank the gods for successful agricultural activities. It is a three day ritual activity that is held every November. Adelowo (1990:166) in his article "Rituals, Symbolism and Symbols in Yoruba Religious Thought" argues that the main difference between worship on the sacred day and worship during the annual festival is that, there are more pronounced and elaborate programmes connected with annual celebrations. Buttressing this point further, Adelowo again affirms that:

This is usually an occasion for jocundity and thanksgiving; people appear in their best and give of their best. The offerings are mostly thank-offerings, and the meals constitute an opportunity of communion between the divinity and his 'children' on the one hand, and then among the 'children themselves on the other'. It is a period for special renewal of covenant relationships. On such occasion, the head of the community, the priest-king, the Pontifex Maximus, is usually involved. It is he who is ultimately responsible for all that happens during the festivals. He also has a special ritual, which, personally or by proxy, he must perform during each festival (1990:166).

Falola (2003:147) posits that through this kind of commemoration of ancestor like Eri "the ruling dynasties in the various states forged relationships with one another by promoting brotherhood relations and the cordial relations among them were sometimes explained in affinal relationships". This is to counter the claims that "the gospel in Igbo land achieved an amazing success where the walls of pagandom collapse Jericho-wise" (Ayandele, 1973:126).

Idigo (2001:177) regrettably comments that in those days, other Igbo communities come to Aguleri to offer sacrifices in the sacred temples to request for one favor or the other and that helped to maintain the link with their root but since their massive conversion into Christianity, these activities became extinct, only Nri keeps to this norm. Idigo (2001:179) further argues that "the Eri and Aguleri connection is avoided in order to give them the opportunity of projecting Nri as the head of the Igbo. But the truth is that Eri is the founder of Igbo race". Notwithstanding

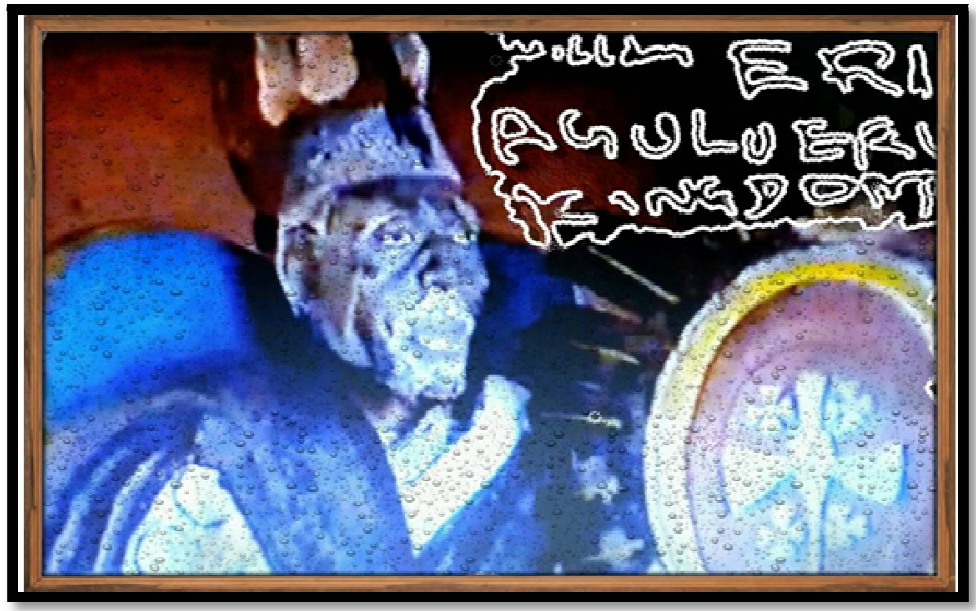

Figure 3: An Artistic Impression of 'Ancestor Eri' The Man Who Is Believed To Be The Progenitor Of The Igbo Race

Source; "Anambra State", (2014)

all these controversies and to put the record straight, Aguleri through the sacred ordination still becomes the ancestral home of the Igbo race (Boston, 1960:55). As a point of emphasis, in Igbo cosmology no Nri man breaks a kola-nut during any social or religio-political gathering in the presence of an Aguleri man because it is a sign of tradocultural respect and seniority and he an Nri does that, it becomes an abomination. In reaffirming this assertion,Ikeanyibe (1999:12) \&Chukwukadibia (2017:16) conclude that "in any complete gathering of the Igbo, Nri may have the right to break the Kolanut only if Aguleri is not represented except with his permission". This is because Eri the father of Aguleri was the founder of Kola-nut (Idigo, 2002:19). Idigo comments that:

At the death of Eri, the scepter of authority was given to Agulu the founder of Aguleri who took over the mantle of rulership of Eri kingdom as the first born of Eri. [sic] Nri the last son of Eri and the priest in Eri family of six sons and a daughter, was the only son who immediately on migration and founding his community at Agu-Ukwu established a centralized authority after obtaining the Odudu Eze from king Agulu of Aguleri (2001:42).

However, Peters (2002:25) argues that "many traditional sacred centers are the centers for particular peoples in their particular geographical and historical circumstances...a sacred center today has to be the center of the entire expanding universe as well as the center of our own lives. That is a big stretch for some traditional ideas". Rowlands (1985:208) affirms that "the medicines mainly used to serve to coordinate rites of pollution removal. According to Mary (2002:111) "this means giving territorial expression to the battle between the forces of good and the forces of evil, and as it were establishing Heaven on Earth". It is also in traditional religion like the whole Igbo religion (Mary, 2002:111), which Akintola (1992:38) describes as the "shrine of mortality".

Ray (1993:268) asserts that prayers, offerings, and sacrifices therefore require the construction of sacred space.Wosien (1992:23) affirms that such "sacred structure space facilitates orientation, provides the framework for worship, and transforms chaos into cosmos, thus making human life possible". Nabofa (1994:45) argues that "such sacred places of worship provide geographical points of reference to religious beliefs and practices. Jett (1995:41) affirms that "because of this power, which is dangerous or beneficent according to those property of one's approach, non-initiates avoid sacred places, while those with the proper ritual knowledge-especially medicine men-may make pilgrimages to 
pray, to renew their ritual equipment and the efficacy of their prayers, to obtain medicinal plants, and to collect sanctified soil and water". However, these festivals have social dimension too (Nti, 1990:3). But unlike the other traditional drums in Aguleri which are strictly used for rituals and other festivals, theOfo sacred ensemble as a symbol of authority for the Igbo kings is either for "social and religious occasions" (Adegbite, 1988:17).

These are the types of symbols that is believed to be imbued with natural powers and they carry a potent aura of sacredness and religiousity (Ejizu, 1986:2). Nabofa (1994:11) argues that "artificial symbols are created by an individual or a group to represent notions of their own. Such symbols usually relate to their own particular experiences and may mean nothing to any other group of persons". According to Onunwa (1990:53) Ofo is a sacred stick of office and authority held by kings, chiefs or family heads. Iheanacho (2005:111) opines that "Ofo is a ritual instrument which symbolizes linage headship and sacred authority". In traditional Igbo culture, according to Ekeke (2012:9) "Ofo depicts that one has the support of the ancestors and deities of the land as he sits on the throne as the king, head or family representative."

It is very significant to mention here that the ancestry genealogy of Eri - the progenitor and great ancestor of Igbo race still exists in Aguleri till date. In fact, through sacred ordination, this royal family that houses the Obu-gadpalace at Enugwu Aguleri headed by His Royal Majesty, Eze A. E. Chukwuemeka Eri [Ezeora XXXiv, Aka ji Ovo Igbo] is the custodian and ritual gate-keeper of the sacred house of Gad that knows the entire ceremonial / ritual repertory for the coronation of Igbo Kings as custom and traditions requires for the Ududu-Eze in traditional Igbo cosmology.

\section{The Ritual Journey for Coronation of Igbo Kings}

The ritual coronation of the Igbo Kings speaks volume where the Udu-eze is in traditional Igbo cosmology. Without it the coronation ritual exercise would not be complete especially where an Nri Kingship and ritual aristocracy is concerned because it is very paramount to the sacred ordination of King where Nri people keep the ritual and sacred order as institutionalised by the ancestors. This is the reason why Onwuejeogwu (1981:87) asserts that it is during this ritual coronation journey. Igwah et al (2014:1) argues that this particular place is very symbolic. Also, it is through this mystical journey during the coronation of a Nri King in Aguelri that (Jeffreys, 1935:347 \& Onwejeogwu, 1981:87) affirms that there is a divine injunction:

A spirit-seeker is consulted for the most propitious days to raise the Odudu. A sacrifice is made on the river-bank, the future divine King points his Ofo over the water and prays that all dangers be removed(1935:348).

Isichei (1976:4); Onwuejeogwu (1981:22) \& Xrydz-Eyutchae (1986:11) affirm that it is "from this point each settlement pursued its own separate existence and development, owing allegiance to Aguleri, where the collective ancestral temple of Eri still stands to this day". Isichei (2004: 286) comments that "his position was not hereditary, and there was often a long interregnum. The new eze was revealed by his supernatural powers; the ritual of his installation included going to the Anambra River, an ancient cradle of Igbo civilization, where he made a mystical journey beneath its waters and recovered sacred stones".The unforgettable, wonderful, well-illustratedand long stages of description of Igwe Obidiegwu Onyeso of Nri at Aguleri during his coronation ritual visitation and journey in 1988 stands the test of time by Igwah et al:

To fulfill the age-long traditional rites for Kingship, in Nri, Igwe Obidiegwu Onyeso, as Igwe-elect, delegation from Nri, which included the late prominent lawyer, Chief Ezebilo Umeadi (SAN)visited Aguleri in 1988. After a brief ceremony at Obuga, at Umuezora, Enugwu Aguleri, Igwe-elect Onyeso and his people went to Igboezunu Aguleri to visit the Okpanime. Obidiegwu Onyeso asked Chief Priest to carry out traditional rites which can act as a blessing. Two Igwes-elect of Nri had been recalled by him. The Otutunzu Aguleri and the Ajani-Ukwu Aguleri were called. Before visiting Ama-Of, went to Ama-Ovo [Ofo] at Umumba, Igboezunu. At Ama-Ofo,the Nri people apologized for the error.The Chief Priest commented that the tree was as old as Aguleri and prayed for a long.He mentioned that the founder of Nri after left his home settled at Agukwu-Nri. The three quarters of Aguleri was handed over by Chief Priest as a symbol of three Ofo sticks. Rituals of praying were performed by Igwe-elect Onyeso and his people for the support and blessing of Oye. Shrine mentioned thatOkpu was their ancestral home after which settlement done at Agu-Ukwu.10th February, 1988,Igwe-elect Onyeso and his delegation, againmade a presentation of some items as homage and sacrificed to the gods.

They gifted a cow, as well as kola-nuts, with 'ego-oji', some bottles of hot drink and tubers of yam, and also a cock.

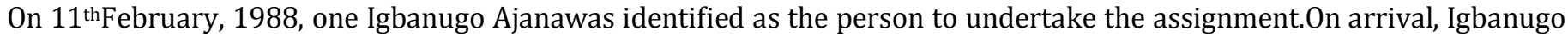
Ajana was made to undergo three days of spiritual purification at Obuga.On 15th February, 1988, the visit of Igwe-elect Onyeso and his people to Aguleri was made from Obuga to the Anambra river, a distance of about three kilometers.At Agbanabo, Igbanugo Ajana jumped into the river and Igbanugo Ajana emerged with some white clay in his palms.'IkekeluEze'is, stone, stick, or whatever, is the Ududu-Eze which were the objects in the palms of the person. After the Ofo given to Igwe-elect his Royal MajestyEze Chukwuemeka Eri sat down on throne of Agulu. After this Obidiegwu Onyeso becamethe Igwe of Nri.After three native weekshe and his delegation left for Nrito recite to Igwe Onyeso the do's and don'ts ['Igu Nso'] of being in possession of the Ofo and Ududu-Eze from Aguleri, as the traditional ruler of Agukwu-Nri.

It is on this position that Onwuejeogwu (1981:168) affirms that "the Nri Kingship has a deep and long connection with Aguleri". (Utazi, 2005:11). Udeani (2007:11) argues that "the view that Nri-Awka is the spiritual and ideological dispersal centre of the Igbo is primarily based on the claims of the clans in this area". Onwuejeogwu states that (1981:114 \& 87) "in the first level only the temple of Uga was formed. It is called "the repository and custodian of genuine tradition" (Hobsbawm, 1983:8). Ekeke (2012:9) called it as a special respect in the community.

Onunwa holds that:

When the king, who is also a priest strikes the Ofo...on the ground [ala] in a ritual of intercessory prayers. It is ritual in which the $\mathrm{Obi}$ strikes the great $O f o$ on the ground to bless his subjects, and offers thanks to the Supreme Deity. (Onunwa,1990:53). 
Bloch (1987:272) called it not only a transcendental model, but also of compromising one. According to Onwubiko (1991: xi) the essence of these [represented] rituals are that they embody the values of the people, they documented the traditional education of the people. Real (1996:48) terms it 'mythic rituals'.

\section{Conclusion}

Through the annual festival of the coming of Eri "Obibia Eri" an ancestor commemoration, and through the sacred ordination of Aguleri as the first son of Eri, Aguleri has taken her rightful position as regards the tradition and culture of the Igbo's in diaspora. In the ritual presentation of the Ududu-eze to any newly elected Kings especially that of the Nri people, the ritual festival tends to reintegrates, reunites and reinforces the binding spiritual forces which ecumenism has not succeeded in breaking its wall Jericho wise in Igbo land. This also marks and repositions Aguleri as the true head of the Igbo nation. Equally significant is the fact that the death of African Traditional Religion is not near because this kind of ritual festival is what ecumenism has failed to conquer among the Igbo people of South-eastern Nigeria.

\section{References}

i. Adegbite, A. 1988. The Drum and Its Role in Yoruba Religion. Journal of Religion in Africa, Vol. 18. Fasc. 1. (February, 1988), 15-26. Available From: http://www.jstor.org/stable/1580834. Accessed: 5 January 2013.

ii. Adelowo, E. D. 1990. 'Rituals, Symbolism and Symbols in Yoruba Religious Thought'. 162-173 Available From: obafemio.weebly.com/uploads/5/1/4/2/5142021/04_1_162pdf. Accessed: 23 September 2012.

iii. Afigbo, A. E. 1983. Traditions of Igbo Origins: A Comment. History in Africa, Vol. 10 (1983), 1-11. Available From: http://www.jstor/stable/3171687. Accessed: 28 April 2014.

iv. Akintola, A. 1992. The Reformed Ogboni Fraternity: Its Origin and Interpretation of Its

v. Doctrines and Symbolism. Ibadan: Valour Publishing Ventures Ltd.

vi. Anambra State Indigenes Italy, 2014. Anambra State Indigenes Italy, photograph. Facebook, 17/07. AvailableFrom:https://www.facebook.com/508771949213836/photos/pcb.667659053325124/667658943325 135/?type=1\&theater, Accessed: 22 July 2014.

vii. Arkin, M. 1989. One People - One Destiny: Some Explorations in Jewish Affairs. Hillcrest: Owen Burgess Publishers.

viii. Ayandele, E. A. 1973. The Collapse of 'Pagandom' in Igbo Land. Journal of the Historical Society of Nigeria, Vol. 7, No. 1 (December 1973), 125-140. Available From: http://www.jstor.org/stable/41856991. Accessed: 7 April 2015.

ix. Babey, F 1976 African Music: A people's Art, Westport: New York: Lawrence Hill and company.

x. Bloch, M. 1987. The Ritual of The Royal Bath In Madagascar: The Dissolution of Death, Birth And Fertility Into Authority cited in Rituals of Royalty: Power and Ceremonial in Traditional Societies(ed) by David Cannadine \& Simon Price (1987), Cambridge: Cambridge University Press. 271-297.

xi. Blackmun, B. W. 1997. Icons and Emblems in Ivory: An Alter Tusk from The Palace of Old Benin. Art Institute of Chicago Museum Studies, Vol.23, No. 2, African Art at The Art Institute of Chicago (1997), 148-163+197-198. Available From: http://www.jstor.org/stable/4104381. Accessed: 10 March 2014.

xii. Boston, J. S. 1960. Notes on Contact Between the Igala And Ibo. Journal of the Historical Society of Nigeria, Vol. 2, No. (December 1960), 52-58. Available From: http://www.jstor.org/stable/41970820. Accessed: 7 April 2015.

xiii. Brown, M. K. 2004. Vodou In the Tenth Department: New York's Haitian Community cited in Beyond Primitivism: Indigenous Religious Traditions and Modernity (ed) by Jacob K. Olupona (2004), New York: Routledge. 164-171.

xiv. Capwell, C. 1993. The Interpretation of History and the Foundation of Authority In The Visnupur Gharana cited in Ethnomusicology and Modern Music History (ed) by Stephen Blum, Philip V. Bohlman \& Daniel M. Neuman (1993), Urbana \& Chicago: University of IIIionois Press. 95-102.

xv. Chidester, D. 1992. Religions of South Africa. London: Routledge.

xvi. Chukwukadibia, E. S. 2017. Igbo go back to Gad: Way Forward to Igbo Nation. Onitsha: Gifted Hearts Publication.

xvii. De Heusch, L. 1994. Myth And Epic In Central Africa cited in Religion In Africa: Experience And Expression (ed) by Thomas D. Blakely, Walter E. A. Van Beek, \& Dennis L. Thomson (1994), London: Heinemann. 229-238.

xviii. Dube, C. 1996. The Changing Context of African Music Performance in Zimbabwe. Zambezia, xxxiii (11). 99-120. Available From: archive.lib.msu.edu/DMC/African Journals/pdfs/Journal of the University of Zimbabwe/vol23n2/juz023002002.pdf. Accessed: 30 January 2013.

xix. Ejizu, C. I. 1986. Ofo, Igbo Ritual symbol, Enugu: Fourth Dimension Publishing co. Ltd.

xx. Ekeke, E. C. 2012. The Symbolism of Offor In Igbo Traditional Religion. 5-10. Available From: www.ajsih.org/files/2.EC.Ekeke. Symbolism.pdf. Accessed: 23 September 2012.

xxi. Eyisi, V.M.C. 2010. Igbo History [With Bible References]. Onitsha: Chuvic Publishers.

xxii. Falola, T. 2003. The Power of African Cultures. New York: University of Rochester Press.

xxiii. Falola, T \& Essien, K. 2007. Invincible Voices: Connections Between African Retentions And Black Freedom Struggle cited in Sacred Drums of Liberation: Religions and Music of Resistance in Africa and the Diaspora. Eritrea: Africa World Press Inc. xi-xxvii.

xxiv. Glocke, A. \& Jackson, L. M. 2011. Dancin' On the Shoulders of Our Ancestors: An Introduction. The journal of Pan African Studies, vol.4, no.6, September 2011. 1-6.

xxv. Available From: www.jpanafrican.com/docs/vol4.no6/4.6-1Dancin.pd Accessed 7 December 2013.

xxvi. Hobsbawm, E. 1983. Mass-Producing Traditions: Europe, 1870-1914. In the Invention of Tradition, (eds) Hobsbawm, E. \& Terrence Ranger, Cambridge: Cambridge University Press. 263-307. 
xxvii. Igwah, R; Okoye, E; Chinwuba, O; Nnechi, J; Nnamah, P; Chikwenze, R; Ikem, E; Ejimofor, G \& Chieze, C. 2014. 'Aguleri Is the Ancestral Home ofThe Igbos, Not Nri'. Available From: www.nairaland.com/1813782/aguleriancestral- home-igbos-not. Accessed: 18 July2014.

xxviii. Idigo, A. C. 2002. Oji: Cola Acuminata - Oji Igbo the Cornerstone of Igbo Traditional Ceremonies. Enugu: Snaap Press Ltd.

xxix. Idigo, F. C. 2001. Eri kingdom of An Igbo king From Israel. Lagos: X-Pose Communications Ltd.

xxx. Idigo, M. C. M.1990. Aguleri History and culture. Lagos: Bantam Press Ltd.

xxxi. Idowu, E. B. 1962. Olodumare: God in Yoruba Belief, London: Longmans.

xxxii. Iheanacho, N. N. 2005. "Symbolism" in Themes in Comparative Religion, W.O. Wotogbe-Weneka (ed) Ado-Ekiti, Hamza Global Press. 100-116.

xxxiii. Ilesanmi, T. M.1996. The Ingenuity of Yoruba Women in The Worship of Orinlase In Ilawe- Ekiti. ORITA Ibadan Journal of Religious Studies, Vol. XXVIII/1-2 (June \& December, 1996), 1-10.

xxxiv. Ikeanyibe, U. 1999. Biblical Evidences: Confirming the Hebrew Origin of Igbo People. Benin: Seed Sowers Publication.

xxxv. 1999. Hebrew and Biblical Sources of Igbo History. Benin: Seed Sowers Publication.

xxxvi. Isichei, E. 1976. A History of Igbo People. London: Macmillan Press Ltd.

xxxvii. ___ 1980 Entirely for God: The life of Michael Iwene Tansi. Ibadan: Macmillan Nigeria Publishers Ltd.

xxxviii. 2004.The Religious Traditions of Africa: A History. London: Praeger Publishers.

xхxix. Jeffreys, M. D. W. 1935. The Divine Umundri King. Africa: Journal of International African Institute, Vol. 8, No. 3 (Jul 1935), 346-354). Available From: http://www.jstor.org.stable/3180419. Accessed: 28 April 2014.

xl. Jett, S. C. 1995. Navajo Sacred Places: Management and Interpretation of Mythic History. The PublicHistorian, Vol. 17, No. 2 (Spring 1995), 39-47. Available From:http://www.jstor.org/sstable/3378125. Accessed: 18 July 2014.

xli. Kaplan, F. E. S. 2000. Some Thoughts on Ideology, Beliefs, and Sacred Kingship AmongThe Edo (Benin) People of Nigeria cited in African Spirituality: Forms, Meanings And Expressions (ed) by Jacob K. Olupona (2000), New York: The Crossroad Publishing Company. 114-151.

xlii. Levine, V. L. 1997. 'Music, Myth, and Medicine in the Choctaw Indian Ballgame' cited in Enchanting Powers: Music in the World's Religions (ed) by Lawrence E. Sullivan(1997), Cambridge: Harvard University Press. $189-218$.

xliii. Lovell, N. 2002. Cords of Blood: Possession and The Making of Voodoo. London: Pluto Press.

xliv. Mary, A. 2002. Pilgrimage to Imeko (Nigeria): An African Church in The Time of The

xlv. Global Village.International Journal of Urban and Regional Research, Oxford,

xlvi. BlackwellPublishers, Vol. 1. 26. 1,106-120.

xlvii. Madukasi, F. C. 1999. 'The cult of saints And Ancestors: Rev. Fr. Cyprian Michael Iwene Tansi, as a Case Study'. Unpublished Long essay, Department of Religious Studies, University of Ibadan.

xlviii. Mbiti, J. S.1975. African Religions and Philosophy, London: Heinemann.

xlix. Metuh, E. I. 1981. God and Man in African Religion. London: Geoffrey Chapman.

1. Macdonald, M. N. 2004. Thinking and Teaching With Indigenous Traditions of Melanesia cited in Beyond Primitivism: Indigenous Religious Traditions and Modernity (ed) by Jacob K. Olupona (2004), New York: Routledge. 314-324.

li. Mcadams, D. P. 1988. Power, Intimacy, andthe Life Story: Personological Inquiries IntoIdentity. New York \& London: The Guilford Press.

lii. Nabofa, M. Y.1988. General Introduction to the Study of Religion, Department of Adult Education, University of Ibadan: University of Ibadan Press.

liii. __ 1994. Symbolism in African Traditional Religion, Ibadan: Paperback PublishersLtd.

liv. _ 1994. Religious Communication: A study in African Traditional Religion, Ibadan: Daystar Press.

lv. National Teachers' Institute, 1990. NCE/DLS Course Book on Cultural \& Creative Arts Cycle 2, Kaduna, Nigeria.

lvi. National Teachers' Institute, 1990. NCE/DLS Course Book on Primary Education Studies Cycle 2, Kaduna, Nigeria.

lvii. Neuman, D. M. 1980. The Life of Music in North India: The Organization of an Artistic Tradition. Detroit: Wayne State University Press.

lviii. Nnamah, P. A. 2002. A Centenary of a Dynasty and Ovala Celebrations fromthe Cradle, cited in Ovala Aguleri 2002 Udo Na Njiko Aguleri Celebrating 100 years of Idigo Dynasty (1900-2000), Aguleri (ed) Paul.A. Nnamah,2002, Aguleri: Okezie Press.7-10.

lix. Nzewi, 0. 2000. The Technology and Music of the Nigerian Igbo Ogene Anuka Bell Orchestra in Leonardo Music Journal, vol. 10, 25-31. Available From: http://muse.jhu.edu/journals/Imj/summary/v010/10.Inzewi.html. Accessed: 10 December 2012.

lx. Omoregie, B.S. 1989. The Man Eri; University magazine, Vol. 112, the institute of African Studies, University of Ibadan, Ibadan, 41-43.

lxi. Onwuejeogwu, M. A.1981. An Igbo Civilization: Nri Kingdom and Hegemony. London: Ethnographica Ltd.

lxii. Ojukwu, O. C. 1998. Toward A Greater Nigeria: The Harsh Realities, Selected Speeches of Dim Emeka Odumegwu Ojukwu 1982-1998. (Compiled) by Okorie k. k \& Ugochukwu, S. S. C, U.S.A: Good Hope Enterprises, Inc.

lxiii. Onunwa, U. R. 1990. Studies in Igbo Traditional Religion, Uruowulu-Obosi, Pacific Press.

lxiv. Okere, T. 2005. Philosophy, Culture and Society in Africa. Nsukka: Afro-Orbis.

lxv. Onwubiko, A. 0. 1991. The Christian Mission and Culture in Africa, (Vol.1): African Thought, Religion and Culture. Enugu: Snaap Press Ltd.

lxvi. Paredes, J. A. 1995. Paradoxes of Modernism in the South East. American Indian Quarterly 19, No. 3: 341-360. 
lxvii. Parrinder, G. 1969. Religion in Africa. London: Penguin Books.

lxviii. Peters, K. E. 2002. Dancing withthe Sacred: Evolution, Ecology, and God. Harrisburg, Pennsylvania: Trinity Press International.

lxix. Ray, B. C.1993. Aladura Christianity: A Yoruba Religion. Journal of Religion in Africa, XXIII, 3.

lxx. Real, M. 1996. Exploring Media Culture: A Guide, London: Sage Publications.

lxxi. Rowe, S. M. 2008. We Dance For Knowledge. Dance Research Journal, Vol. 40, No. 1

lxxii. (Summer 2008), 32-44. Available From: http://www.jstor.org/stable/20527591. Accessed: 18 July 2014.

lxxiii. Rowlands, M. 1985. Notes onthe Material Symbolism of Grassfields Palaces. Paideuma, Bd. 31, Palaces and Chiefly Households in the Cameroon Grassfields (1985); 203-213. Available From: http://www.jstor.org/stable/23076461. Accessed: 10 March 2014.

lxxiv. Saner, R. 1987. Sacred Space. The Georgia Review, Vol. 41, No. 1. 4 (Winter 1987), 721-735. Available From: http://www.jstor.org/stable/41399359. Accessed: 8 April 2014.

lxxv. Uchendu, C. C. 1965. The Igbo of South East Nigeria. Chicago: Holt, Rinehart and Winston, Inc.

lxxvi. Udeani, C. 2007. Inculturation As Dialogue: Igbo Culture and The Message of Christ. Amsterdam-New York, Rodopi.

lxxvii. Utazi, C. 2005. The Concept of an Omnipotent God in Africa - The Igbo Traditions. Available From: www.slideshare.net/chichieze/the-concethe-concept-of-an-omniotent-god-inafrica-the-igbo-traditionspt-of-anomnipotent-god-in-africa-the-igbo-traditions. Accessed: 17 January 2014. 1-26.

lxxviii. Waterman, R. A. 1955. 'Music in Australian Aboriginal Culture-Some Sociological and Psychological Implication'. Music Therapy 5: 40-50. Reprinted in Readings in 1971

lxxix. Ethnomusicology (ed) by D. P. McAllester (1971), New York: Johnson Reprint Corporation:167-174.

lxxx. Williams. 1988. The Representation and Reality of Religion in Dance. By Hanna, J. L.

lxxxi. (Reviewed).Journal of the American Academy of Religion. (JAAR), LV/2: 281-306. 72-85. Available From: ashm.press.illinois.edu/6.2/6-2ReviewArticle_Williams72-85pdf. Accessed: 31 January 2014.

lxxxii. Wosien, M. G. 1992. Sacred Dance: Encounter with the Gods. Singapore: Thames and Hudson.

lxxxiii. Weightman, B. A. 1996. Sacred Landscapes andthe Phenomenon of Light. Geographical Review, Vol. 86, No. 1 (Jan 1996), 59-71. Available From:

lxxxiv. http://www.jstor.org/stable/215141. Accessed: 9 April 2014.

Ixxxv. Xrydz - Eyutchae, C. 1986. 'Anambra Is the Ancestral Home of the Igalas', Daily Star Press Ltd, Enugu: August 11, 18. 